\title{
Pheromone Trap Catch of Harmful Microlepidoptera Species in Connection with the Chemical Air Pollutants
}

\author{
L. Nowinszky ${ }^{1}$, J. Puskás ${ }^{1}$, G. Barczikay² \\ ${ }^{1}$ University of West Hungary Savaria University centre, Szombathely, Károlyi Gáspár Square 4 \\ ${ }^{2}$ County Borsod-Abaúj-Zemplén Agricultural Office of Plant Protection and Soil Conservation \\ Directorate, Bodrogkisfalud, Vasút Street. 22 \\ lnowinszky@gmail.com,pjanos@gmail.com
}

\begin{abstract}
In this study, seven species of Microlepidoptera pest pheromone trap collection presents the results of the everyday function of the chemical air pollutants $\left(\mathrm{SO}_{2}, \mathrm{NO}, \mathrm{NO}_{2}, \mathrm{NO}_{x}, \mathrm{CO}, \mathrm{PMIO}, \mathrm{O}_{3}\right)$. Between 2004 and 2013 Csalomon type pheromone traps were operating in Bodrogkisfalud $\left(48^{\circ} 10^{\prime} \mathrm{N} ; 21^{\circ} 21 \mathrm{E}\right.$; Borsod-AbaújZemplén County, Hungary, Europe). The data were processed of following species:

Spotted Tentiform Leafminer (Phyllonorycter blancardella Fabricius, 1781), Hawthorn Red Midged Moth (Phyllonorycter corylifoliella Hübner, 1796), Peach Twig Borer (Anarsia lineatella Zeller, 1839), European Vine Moth (Lobesia botrana Denis et Schiffermüller, 1775), Plum Fruit Moth (Grapholita funebrana Treitschke, 1846), Oriental Fruit Moth (Grapholita molesta Busck, 1916) and Codling Moth (Cydia pomonella Linnaeus, 1758). The relation is linear, logarithmic and polynomial functions can be characterized.
\end{abstract}

Keywords: Microlepidoptera, pests, pheromone traps, air pollution

\section{INTRODUCTION}

Since the last century, air pollution has become a major environmental problem, mostly over large cities and industrial areas (Cassiani et al. 2013).

It is natural that the air pollutant chemicals influence the life phenomena of insects, such as flight activity as well.

According to Butler and Trumble (2008) the pollutants are harmful onto the plants of the terrestrial ecosystems and the insects, including air pollutants, such as ozone, sulphur oxides $\left(\mathrm{SO}_{\mathrm{x}}\right)$, nitrogen oxides $\left(\mathrm{NO}_{\mathrm{x}}\right)$, carbon oxides $(\mathrm{CO})$, fluoride and acid rain (fog and rain) and polluting metals and heavy metals.

The population density reduction can be most frequently explained by the toxicity of pollutants (Kozlov et al., 1996). However, there are some species which prefer pollutants, they can product strong growth and consequently cause serious damage to the polluted forests (Baltensweiler, 1985). There is a response of insect populations change from negative to positive environmental pollution (Führer, 1985).

There are some hypotheses which refer to the polluting effect on plant consuming insects. These are following:

1) it causes a change in the quality of the habitat on plant consuming ones,

2) it may modify the quality of the plant,

3 ) it is harmful for the natural enemy, so they decrease because of this or they disappear (Zvereva and Kozlov, 2000).

Kozlov and Haukioja (1993) publish the densities of males of the Large Fruit-tree Tortrix Archips podana Scopoli which were determined by pheromone traps in the Lipetsk district, central Russia, in 1991.

The sulphur dioxide was significant at Lipetsk among industrial emissions. The individual density of A. podana reached a peak at about 3-7 km from the nearest source of emission. 


\section{Nowinszky et al.}

According to Malinowski (1992) there are differences among the answers of different animal groups given to the air pollution. Sometimes these separate clearly the different subgroups, in other cases, their susceptibility or resistance seems to be individual against air pollution against air pollution.

Some examples are given below:

Terrestrial insects: distinct types of response to $\mathrm{SO}_{2}$ pollution have been identified which distinguish some groups of land-living insect, for example: Very sensitive: e.g. many butterflies and moths; moderately sensitive, e.g. the Pine Engraver (Ips dentatus Sturm) and the Pine Flat-bug Aradus cinnamoneus Panz.; very tolerant and sometimes benefitted by $\mathrm{SO}_{2}$ pollution: aphids.

The abundance and dynamics of the European Spruce Bark Beetle (Ips typographus Linnaeus) populations was evaluated by Grodzki et al. (2014) in 60-80 year old spruce stands in Norway. The mean daily capture of beetles in pheromone traps was significantly higher at sites where the $\mathrm{O}_{3}$ level was higher.

The particulate matter adsorb toxic materials (e.g. metals, mutagenic substances) as well as bacteria, viruses, fungi and promote their getting into the body. PM10 can be cause irritation in the lung and mucous membrane (Dockery 2009). 211 lives could have been saved in Hungary yearly by the reduction of PM10 to yearly mean of $20 \mu \mathrm{g} / \mathrm{m}^{3}$ (Bobvos et al. 2014). Research groups studied in Europe in several cities of PM10 pollution (Makra et al. 2011, 2013; Papanastasiou \& Melas 2004, 2008, 2009; Papanastasiou et al. 2010). According to Vaskövi et al. (2014) and Chłopek (2013) the yearly mean concentration of PM10 is generally higher near the main traffic roads than in areas with less traffic.

However, the studies examining the activity and daily pheromone trapping the insects in connection with air pollution we not found in the literature.

\section{Material AND Methods}

Between 2004 and 2013 Csalomon type pheromone traps were operating in Bodrogkisfalud (48 $10^{\circ}$ N, 21 ${ }^{\circ} 21^{\prime}$ E; Borsod-Abaúj-Zemplén County, Hungary, Europe). These traps attracted seven Microlepidoptera species. Every year 2-2 traps per species were collected; one night after a 2-2 catching, data were available. Data on the Hawthorn Red Midget Moth (Phyllonoricter corylifoliella Hbn.) were collected between 2008 and 2013 only. The catch data of the collected species is displayed in Table 1.

Table1. The Number and Observing Data of the Examined Species

\begin{tabular}{|c|c|c|}
\hline \multirow{2}{*}{ Species } & \multicolumn{2}{|c|}{ Number of } \\
\hline & moths & data \\
\hline $\begin{array}{l}\text { Gracillariidae } » \text { Lithocolletinae } \\
\text { Spotted Tentiform Miner } \\
\text { Phyllonorycter blancardella } \text { Fabricius, } 1781\end{array}$ & 66,712 & 3,054 \\
\hline $\begin{array}{l}\text { Gracillariidae »Lithocolletinae } \\
\text { Red Midget Moth } \\
\text { Phyllonorycter corylifoliella } \text { Hübner, } 1796\end{array}$ & 10,212 & 1,834 \\
\hline $\begin{array}{l}\text { Gelechiidae » Anacampsinae } \\
\text { Peach Twig Borer } \\
\text { Anarsia lineatella Zeller, } 1839\end{array}$ & 9,415 & 2,497 \\
\hline $\begin{array}{l}\text { Tortricidae » Olethreutinae } \\
\text { European Vine Moth } \\
\text { Lobesia botrana Denis et Schiffermüller, } 1775\end{array}$ & 9,430 & 2,549 \\
\hline $\begin{array}{l}\text { Tortricidae »Olethreutinae } \\
\text { Plum Fruit Moth } \\
\text { Grapholita funebrana Treitschke, } 1846\end{array}$ & 30,941 & 3,176 \\
\hline $\begin{array}{l}\text { Tortricidae» Tortricinae } \\
\text { Oriental Fruit Moth } \\
\text { Grapholita molesta Busck, } 1916\end{array}$ & 17,271 & 3,086 \\
\hline $\begin{array}{l}\text { Tortricidae » Olethreutinae } \\
\text { Codling Moth } \\
\text { Cydia pomonella } \text { Linnaeus, } 1758\end{array}$ & 9,694 & 2,658 \\
\hline
\end{tabular}

The distance between the traps were 50 meters and they were in operation all the year on the same branch of leafy trees or vines. The height of each species was different from 1.5 to 2 meters. The traps operated from start of April to the end of September. The capsules exchange was in every 6-8 weeks 
as it was proposed by Tóth (2003). The number of caught moths was daily recorded. This is different from the general practice, because generally the catch of the traps is counted two or three days together in most cases.

\section{Air pollutants Material}

The values of the chemical air pollutants: $\mathrm{SO}_{2}, \mathrm{NO}, \mathrm{NO}_{2}, \mathrm{NO}_{\mathrm{x}}, \mathrm{CO}, \mathrm{PM} 10, \mathrm{O}_{3}$ (in milligram per cubic meter) were measured in nearest automatic measurement station Hernádszurdok $\left(48^{\circ} 28^{\prime} 98^{\prime \prime} \mathrm{N}\right.$, $\left.21^{\circ} 12^{\prime} 38^{\prime \prime} \mathrm{E}\right)$. Distance between the two villages from each other is $37 \mathrm{~km}$ as the crow flies.

From the catching data of the examined species, relative catch (RC) data were calculated for each observation posts and days. The $\mathrm{RC}$ is the quotient of the number of individuals caught during a sampling time unit ( 1 day) per the average number of individuals of the same generation falling to the same time unit. In case of the expected averaged individual number the RC value is 1 (Nowinszky, 2003). The introduction of RC enables us to carry out a joint evaluation of materials collected in different years and at different traps.

The data from different years were treated with combined.

The number of the chemical air pollutants and the moths caught was calculated with consideration to the method of Sturges (Odor and Iglói, 1987).

The $\mathrm{RC}$ values of all species were arranged into the proper classes.

The results obtained are plotted. We determined the regression equations, these levels of significance, which were shown in the figures.

\section{RESUlTS AND DisCuSSION}

All of our results are shown in Table 2.

Table2. The behaviour types of the examined species

\begin{tabular}{|l|c|c|c|c|c|c|c|}
\hline \multicolumn{1}{|c|}{ Species } & $\mathrm{SO}_{2}$ & $\mathrm{NO}_{2}$ & $\mathrm{NOx}$ & $\mathrm{NO}$ & $\mathrm{CO}$ & $\mathrm{O}_{3}$ & PM10 \\
\hline Ph. blancardella Fabr. & - & $\mathrm{D}$ & $\mathrm{I} \rightarrow \mathrm{D}$ & $\mathrm{I}$ & $\mathrm{I}$ & $\mathrm{I} \rightarrow \mathrm{D}$ & $\mathrm{I}$ \\
\hline Ph. corylifoliella Hbn. & - & $\mathrm{I} \rightarrow \mathrm{D}$ & $\mathrm{I} \rightarrow \mathrm{D}$ & $\mathrm{I}$ & $\mathrm{D}$ & $\mathrm{I} \rightarrow \mathrm{D}$ & $\mathrm{I}$ \\
\hline A. lineatella Zeller & $\mathrm{I} \rightarrow \mathrm{D}$ & $\mathrm{I} \rightarrow \mathrm{D}$ & - & - & $\mathrm{I} \rightarrow \mathrm{D}$ & $\mathrm{I} \rightarrow \mathrm{D}$ & - \\
\hline L. botrana Den. et Schiff. & - & $\mathrm{I}$ & $\mathrm{I}$ & $\mathrm{I} \rightarrow \mathrm{D}$ & - & $\mathrm{I}$ & $\mathrm{I}$ \\
\hline G. funebrana Tr. & - & $\mathrm{I}$ & $\mathrm{I}$ & - & - & $\mathrm{I}$ & $\mathrm{I}$ \\
\hline G. molesta Busck & $\mathrm{I} \rightarrow \mathrm{D}$ & $\mathrm{I}$ & $\mathrm{I}$ & - & - & $\mathrm{I}$ & $\mathrm{I}$ \\
\hline C. pomonella $\mathrm{L}$. & $\mathrm{I} \rightarrow \mathrm{D}$ & $\mathrm{I} \rightarrow \mathrm{D}$ & $\mathrm{I} \rightarrow \mathrm{D}$ & $\mathrm{I} \rightarrow \mathrm{D}$ & $\mathrm{I} \rightarrow \mathrm{D}$ & $\mathrm{I} \rightarrow \mathrm{D}$ & $\mathrm{I}$ \\
\hline
\end{tabular}

Notes: (I=increasing, $D=$ decreasing, $I \rightarrow D$ : increasing after decreasing, $-:$ not significant)

We found that the behaviour of the studied species can be divided into three types: if the air pollution increases the catch increase or decrease. In the third group there is an increase first and then a decrease will appear. Some of these types of behaviour some figures are also presented for each pollutant.

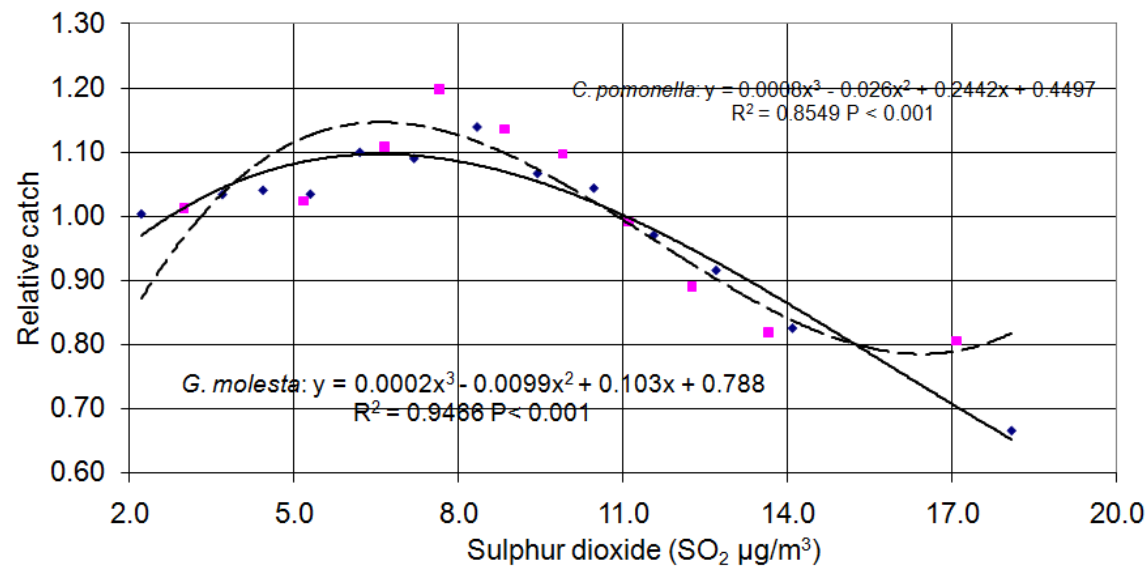

Figure1. Pheromone trap catch of the Grapholita molesta Busck and Cydia pomonella Linnaeus in connection with the sulphur dioxide $\left(\mathrm{SO}_{2}\right)$ content of the air (Bodrogkisfalud, 2004-2013) 


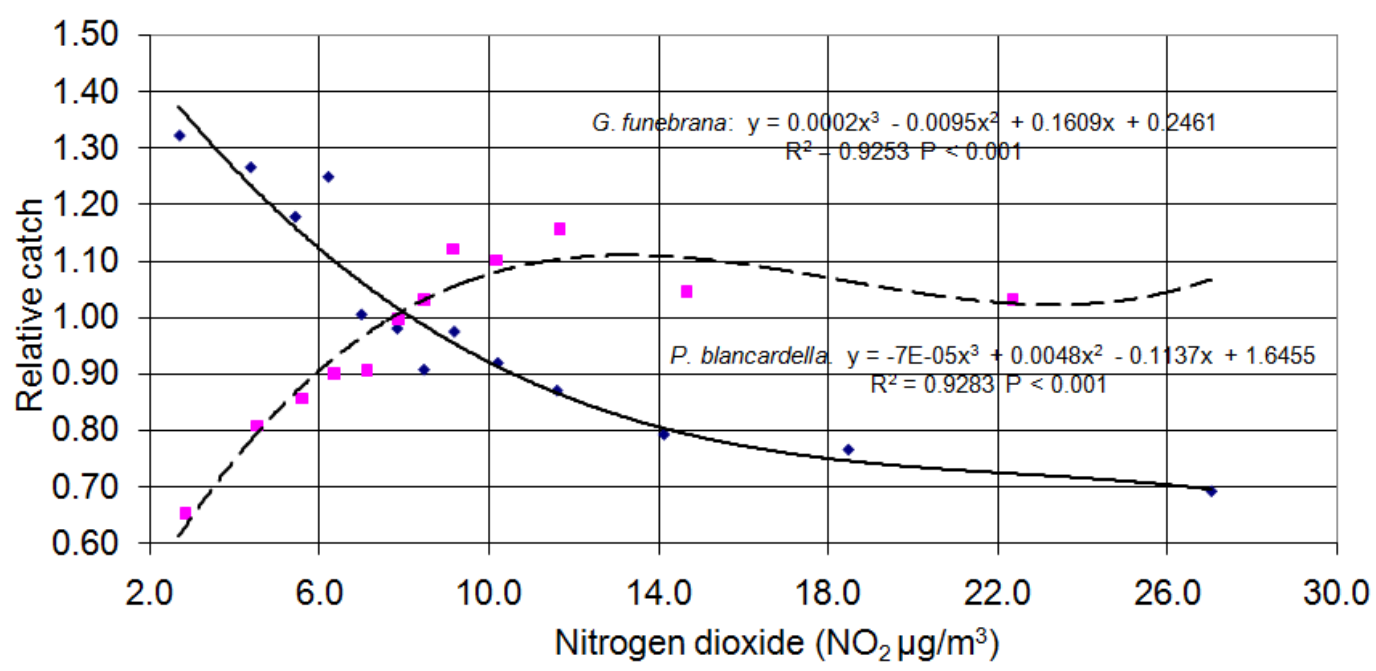

Figure2.1. Pheromone trap catch of the Phyllonorycter blancardella Fabricius and Grapholita funebrana Treitschke in connection with the nitrogen dioxide $\left(\mathrm{NO}_{2}\right)$ content of air (Bodrogkisfalud, 2014-2013)

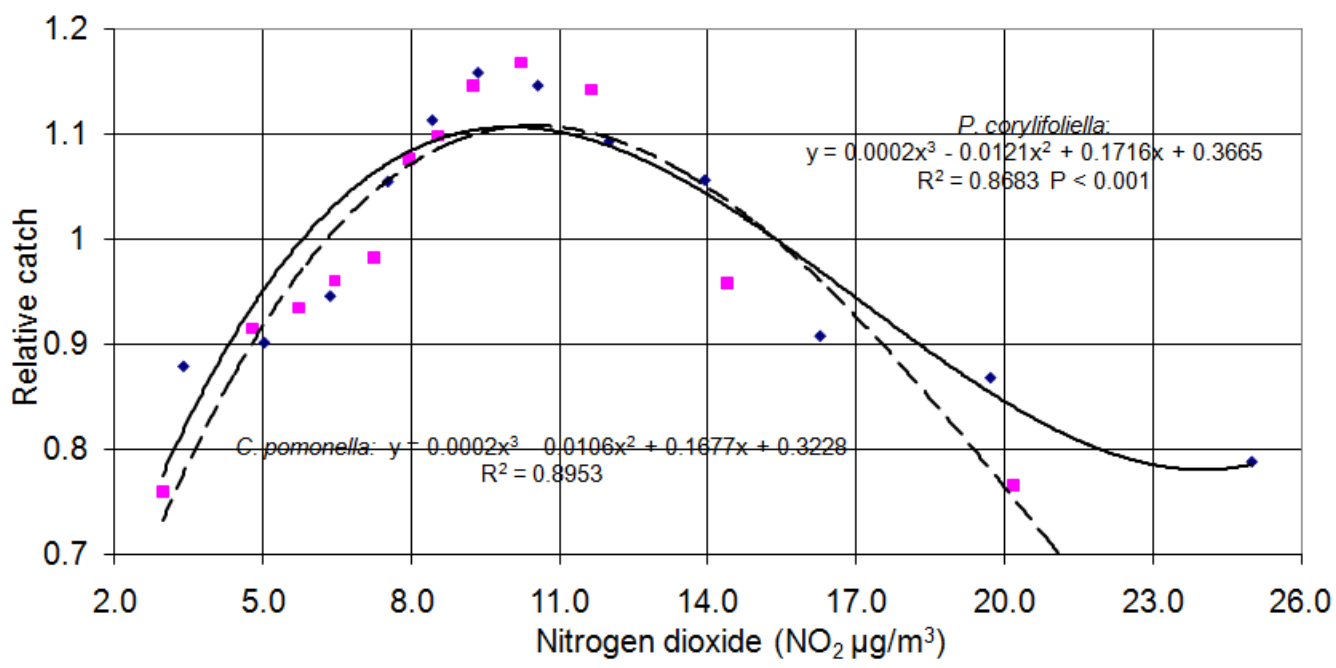

Figure2.2. Pheromone trap catch of the Phyllonorycter corylifoliella Hübner and Cydia pomonella Linnaeus in connection with the nitrogen dioxide $\left(\mathrm{NO}_{2}\right)$ content of air (Bodrogkisfalud, 2008-2013 and 2003-2013)

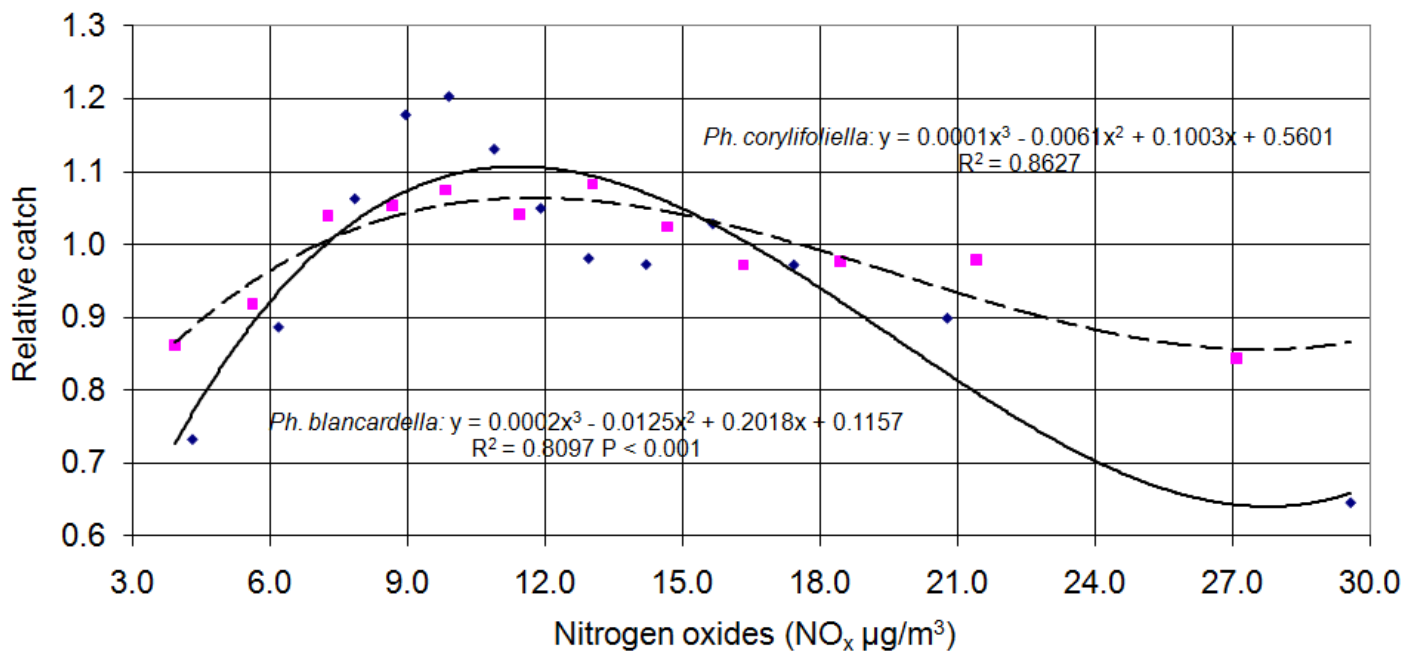

Figure3.1. Pheromone trap catch of Phyllonorycter blancardella Fabricius and Phyllonorycter corylifoliella Hübner in connection with the nitrogen oxides $\left(N O_{x}\right)$ contents of air (Bodrogkisfalud 2004-2013 and 20082013) 
Pheromone Trap Catch of Harmful Microlepidoptera Species in Connection with the Chemical Air Pollutants

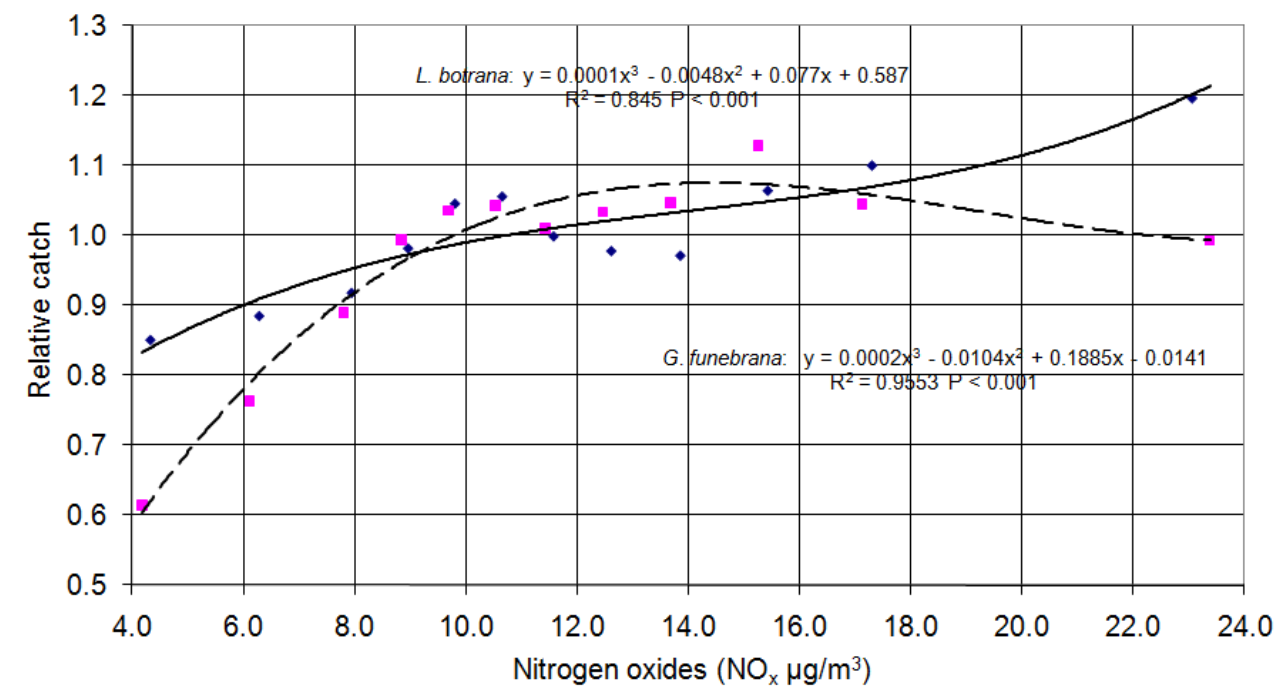

Figure3.2. Pheromone catch of Lobesia botrana Denis et Schiffermüller and Grapholita funebrana Treitschke in connection with the nitrogen oxides $\left(\mathrm{NO}_{x}\right)$ content of air (Bodrogkisfalud, 2004-2013)

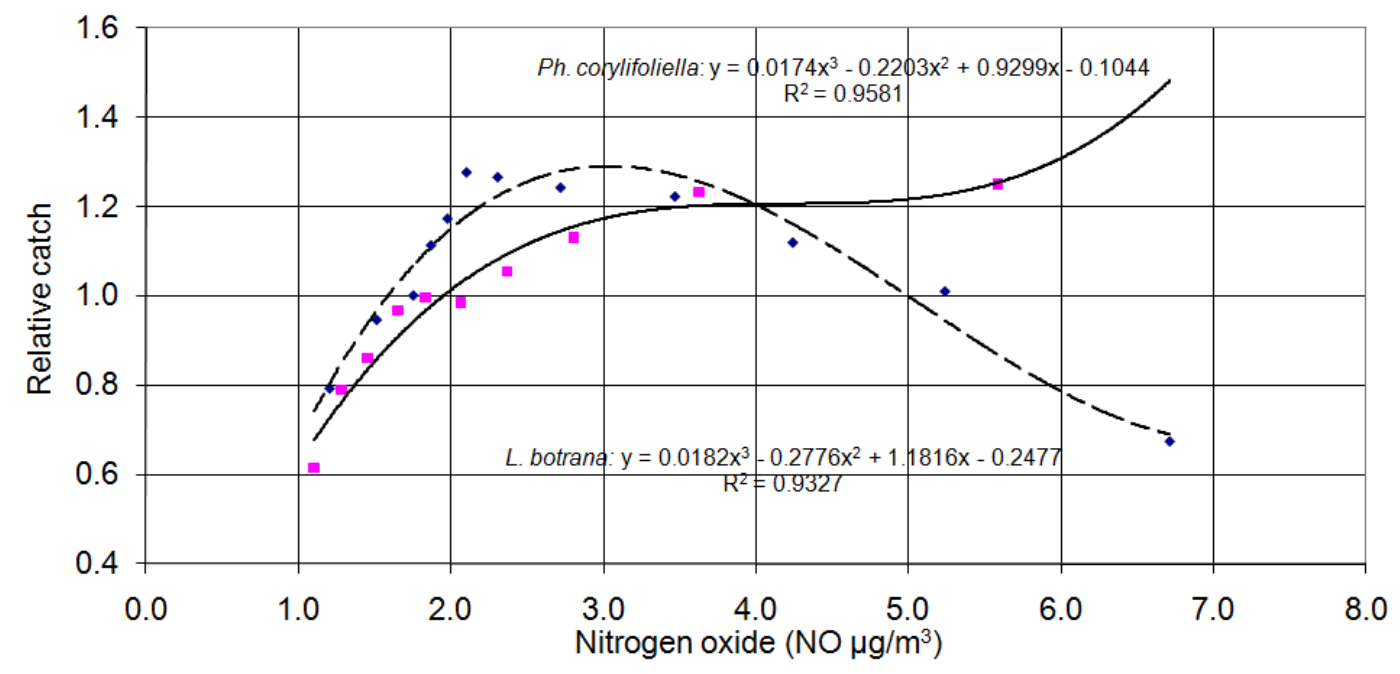

Figure4. Pheromone trap catch of the Phyllonorycter corylifoliella Hübner and Lobesia botrana Denis et Schiffermülle in connection with nitrogen oxide (NO) content of air (Bodrogkisfalud, 2008-2013 and 20042013)

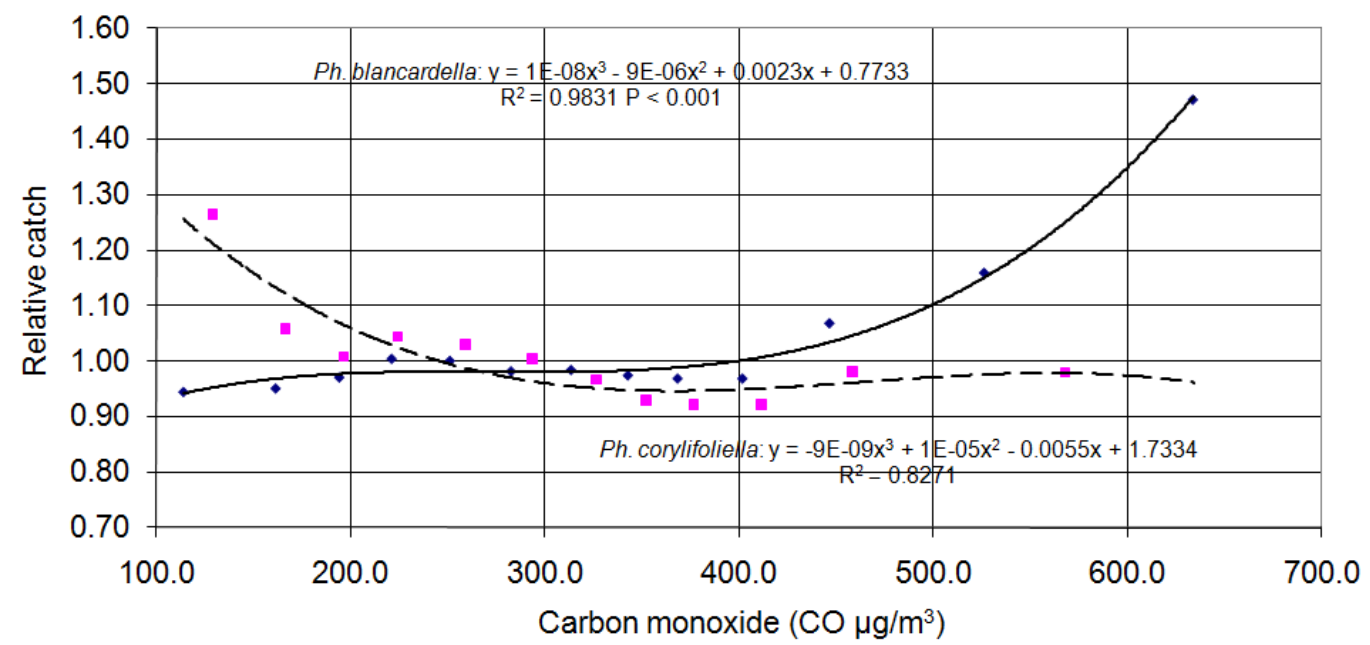

Figure5.1. Pheromone trap catch of the Phyllonorycter blancardella Fabricius and Phyllonorycter corylifoliella Hübner in connection with carbon monoxide (CO) content of air (Bodrogkisfalud, 2004-2013 and 2008-2013) 


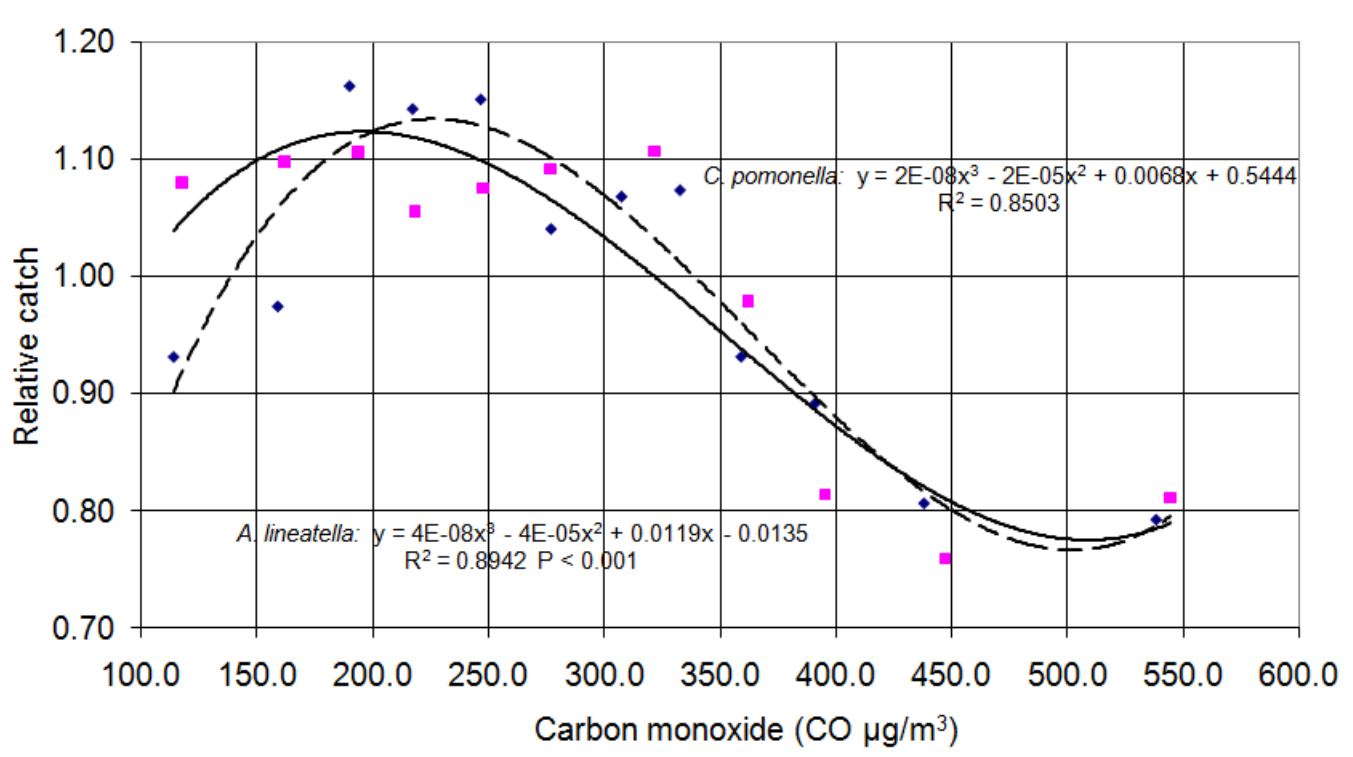

Figure5.2. Pheromone trap catch of the Anarsia lineatella Zeller and Cydia pomonella Linnaeus in connection with the carbon monoxide (CO) content of air (Bodrogkisfalud, 2004-2013)

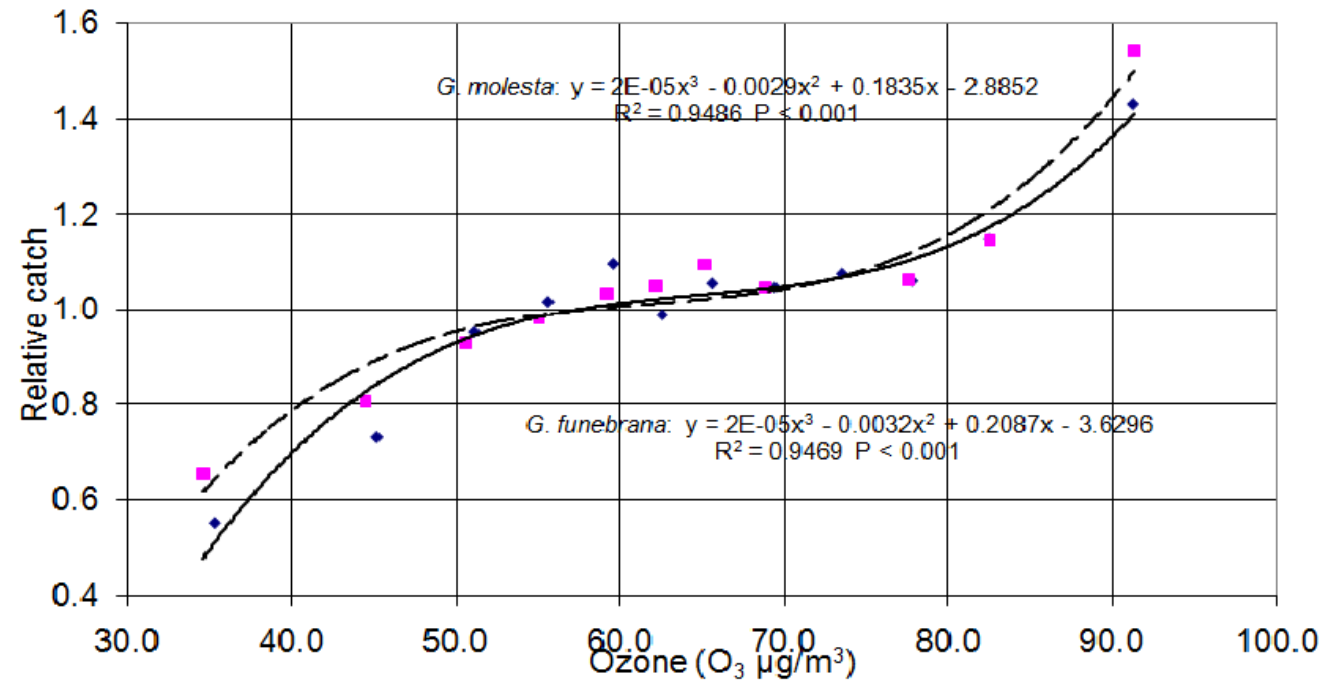

Figure6.1. Pheromone trap catch of the Grapholita funebrana Treitschke and Grapholita molesta Busck in connection with ozone $\left(\mathrm{O}_{3}\right)$ content of air (Bodrogkisfalud, 2004-2013)

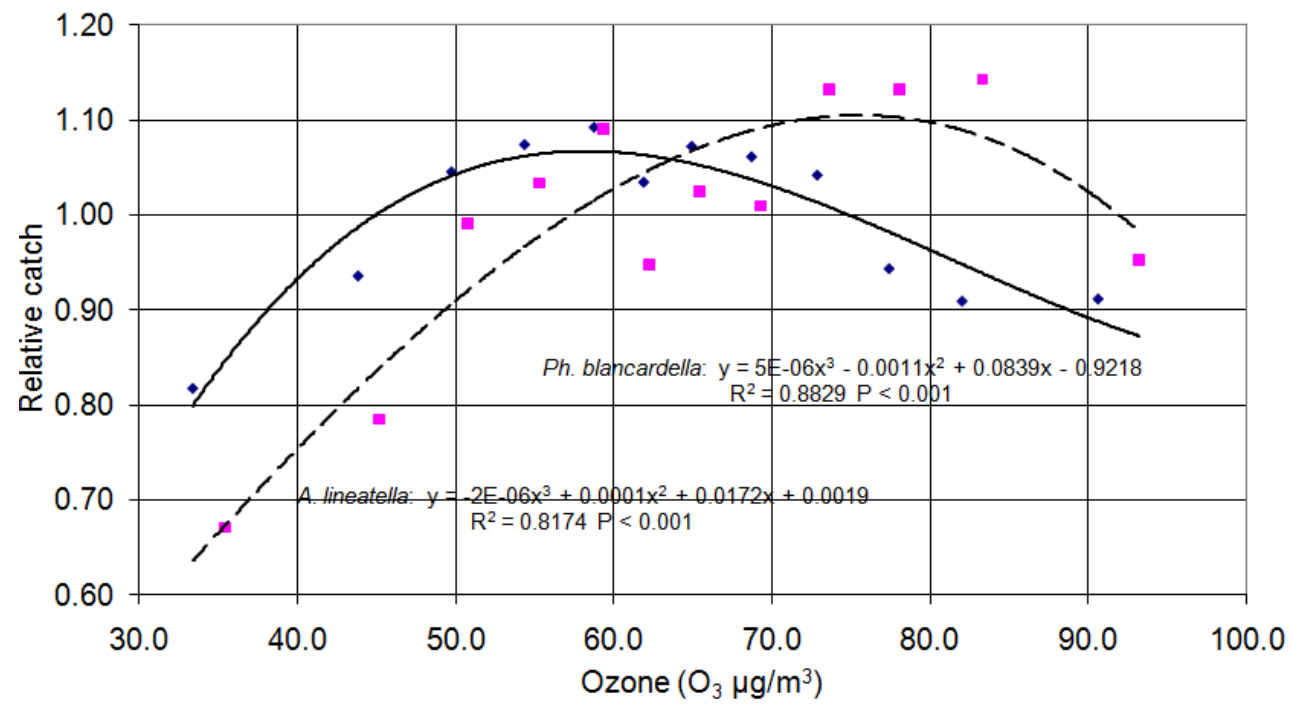

Figure6.2. Pheromone trap catch of the Phyllonorycterblancardella Fabricius and Anarsia lineatella Zeller in connecton with the ozone $\left(\mathrm{O}_{3}\right)$ content of air (Bodrogkisfalud, 2004-2013) 
Pheromone Trap Catch of Harmful Microlepidoptera Species in Connection with the Chemical Air Pollutants

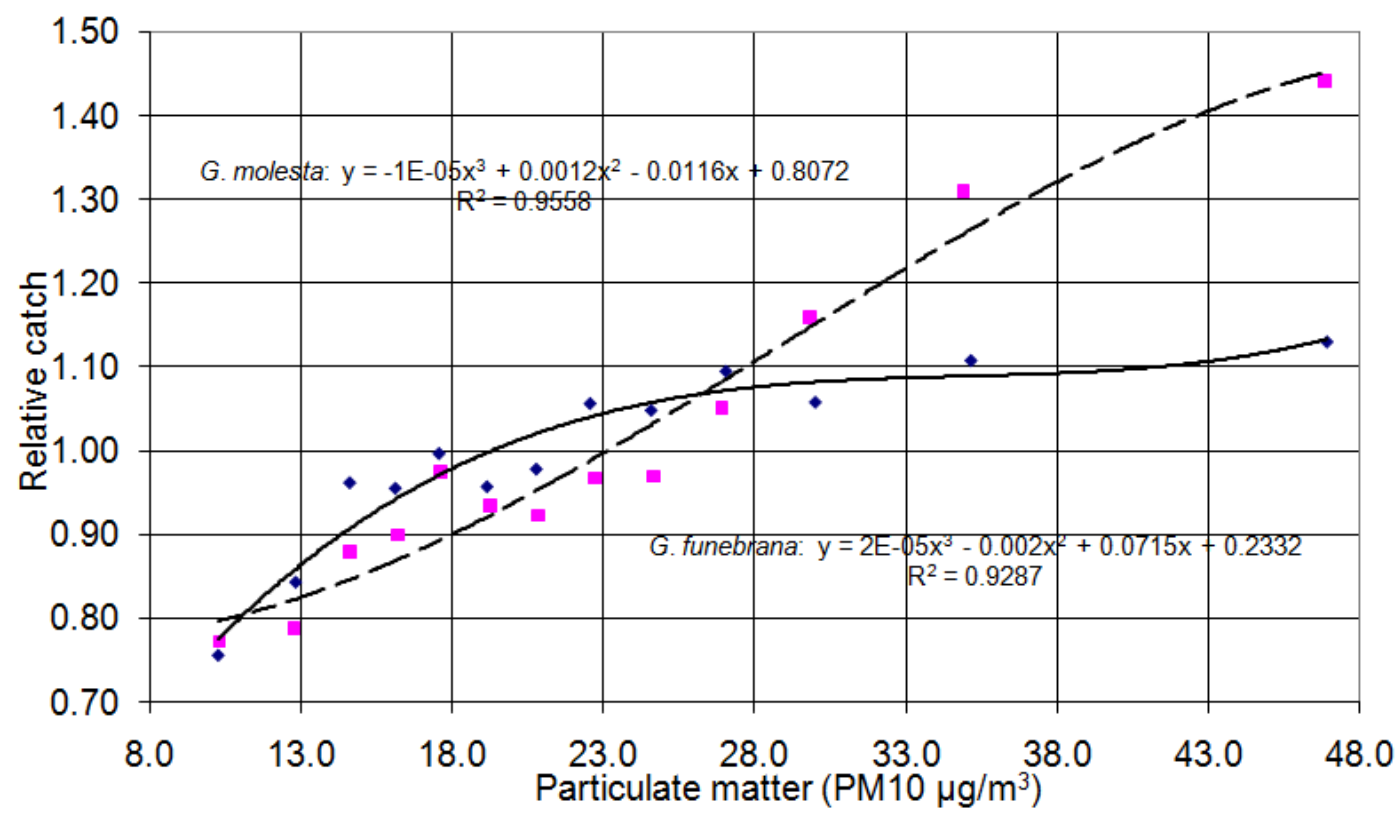

Figure7. Pheromone trap catch of the Grapholita funebrana Treitchke and Grapholita molesta Busck in connection with the particulate matter (PM10) content of air (Bodrogkisfalud, 2004-2013)

Our results are without antecedents in the literature. Partly because the catching results of pheromone traps are not suitable for tests on daily events, and partly because of flight activity and trapping insects of our knowledge, have not been studied in entomologists.

We can only mention one of our own studies, dealing with examination between the pheromone trap catches and PM10 (Nowinszky et al. 2015).

Our results may explain at present only assumptions, but they cannot even prove or disprove. The increase the content of particular matter in air may therefore increase the catch, because the light is reflected from the solid particles, thus increasing the amount of polarized light by day and night. The pheromone traps that male moths collected throughout the day. As we have previously demonstrated the polarized light increases the activity of insects (Nowinszky et al, 1979, 2010a, 2010b, 2012a, 2012b, Nowinszky \& Puskás 2009, 2010, 2011, 2012, 2013a, 2013b, 2014). Another possibility is that the solid particles of the pheromone molecules bind well, so the greater activity male moths need for finding the females.

The particulate matters adsorb toxic materials (e.g. metals, mutagenic substances) as well as bacteria, viruses, fungi and promote them getting inside the body.

The emission of solid materials (dust, PM10) in Hungary from the early 90s fell by almost half, initially strongly, later with declining pace. The main pollutants are the industry, energy production and the population, but growing of transport sector can be seen during last years. Today, more and more attention is paid to this pollutant. Research results have proved that the health effects of dust is far greater than previously thought. The small amount of material in the air, which is highly toxic, bind on the surface of the small size particles (PM2.5) and together with these particles they directly pass into the blood through the respiratory system. We know little about their effect has on the insects however.

The response of different insect groups (Microlepidoptera, Macrolepidoptera, Trichoptera) to environmental factors is strikingly different. The only exception is the temperature and the (polarized) moonlight. The temperature is one reason because special temperature values are necessary for the flight activity. This is not the same value for different species but at a higher temperature the activity can be higher. Another reason is that the flying period is relatively short and it is in that season when the rough changes of temperature are very rare. The moonlight and especially its polarized proportion significantly increase the flight activity (Nowinszky, 2004 and 2008).

We do not know the impact of other pollutants on insect flight activity in the air.

This opposite form of behaviour may be the many reasons. The claim and tolerance to environmental factors of the species are different. Environmental factors interact with each other to exert their ef- 


\section{Nowinszky et al.}

fects. Thus the same factor can be different effect. The species have different survival strategy (Nowinszky, 2003). Adverse effects of two possible answers: passivity, or hiding or even increased activity, because you want to ensure the survival of the species. Therefore, the insect do "to carry out their duties in a hurry."

It may be more of the reason of this for contrary behavioural forms:

The different species needs different circumstances and tolerance to environmental factors.

Environmental factors interact with each other to exert their effects. Thus the same factor can cause different influence.

The different species have other survival strategy (Nowinszky, 2003). It is possible two answers to the unfavourable environmental factors: passivity (e.g. hiding) or even increased activity, because the insect wants to ensure the survival of the species. Therefore, he does quickly his tasks.

The fact that on the higher and increasing values of air pollutants the catches are not suddenly, but gradually decline, we deduce that the tolerance and response of insect specimens adverse effects to individually change.

Further studies are planned. We will continue our research in other insect species and trap types for analyses.

Preliminary results are published with a view that researchers should be aware that the tests should be conducted on this neglected but important topic of study.

\section{REFERENCES}

Baltensweiler,W., (1985):'Waldsterben': forest pests and air pollution. Z. Angew. Entomol. 99: 7785.

Bobvos J., Szalkai M., Fazekas B. \& Páldy A. (2014): Health impact assessment of suspended particulate matter in some Hungarian cities. (in Hungarian), Egészségtudomány 58 (3): 11-26.

Buttler C. D., Trumble J. T. (2008): Effect of pollutants on bottom-up and top-down process in insect-plant interactions. Environmental Pollution, 56: 1-10.

Cassiani M, Stohl A, Eckhardt S (2013): The dispersion characteristics of air pollution from the world's megacities. Atmos Chem Phys 13: 9975-9996. doi:10.5194/acp-13-9975-2013

Chłopek Z. (2013): Examination of a particulate matter PM10 immission model in the environment around road transport routes. Repozytorium CeON, 1-37.

Dockery D. W. (2009): Health Effects of Particulate Air Pollution. Annals of Epidemiology 19 (4): 257-263.

Führer, E. (1985): Air pollution and the incidence of forest insect problems. Z. angew. Entomol. 99: 371-377.

Grodzki W, McManus M, Knízek M, Meshkova V, Mihalciuc V, Novotny J, Turcani M, Slobodyan Y. (2014): Occurrence of spruce bark beetles in forest stands at different levels of air pollution stress. Environmental Pollution 130 (1): 73-83.

Kozlov, M. V., Haukioja, E. (1993): Density and size of Archips podana Lepidoptera: Tortricidae males in an air pollution gradient as revealed by pheromone traps. Environmental Entomology 22(2): 438-444.

Kozlov, M.V., Zvereva, E.L., Selikhovkin, A.V. (1996): Decreased performance of Melasoma lapponica (Coleoptera: Chrysomelidae) fumigated by sulfur dioxide: direct toxicity vs. host plant quality. Environ. Entomol. 25: 143-146.

Makra L., Matyasovszky I., Guba Z., Karatzas K. \& Anttila P. (2011): Monitoring the long-range transport effects on urban PM10 levels using 3D clusters of backward trajectories. Atmospheric Environment 45: 2630-2641.

Makra L., Ionel I., Csépe Z., Matyasovszky I., Lontis N., Popescu F. \& Sümeghy Z. (2013): The effect of different transport modes on urban PM10 levels in two European cities. Science of the Total Environment 458-460: 36-46.

Malinowski, H. (1992): Influence of air pollution on insect populations - resistance changes, Air Pollution and Interactions between Organisms in Forest Ecosystems: Proceedings of the $15^{\text {th }}$ IUFRO 
International Meeting of Specialists on Air Pollution Effects on Forest Ecosystems, edited by M Tesche and S Feiler

Mcnary, T. J., Milchunas, D. G., Leetham, J. W., Lauenroth, W. K., Dodd J. L. (1981): Effect of Controlled Low Levels of S02 on Grasshopper1 Densities on a Northern Mixed-Grass Prairie Journal of Economic Entomology, 74: 91-93.

Nowinszky L. \& Puskás J. 2009. Light-trap catch of European Corn Borer Ostrinia nubilalis Hbn. depending on the moonlight. Acta entomologica serbica, 14 (2): 163-174.

Nowinszky L. \& Puskás J. 2010. Possible reasons for reduced light trap catches at a full moon. Shorter collecting distance or reduced flight activity. Advances in Bioresearch, 1 (1): 205-220.

Nowinszky L. \& Puskás J. 2011. Light trapping of Helicoverpa armigera in India and Hungary in relation with moon phases. The Indian Journal of Agricultural Sciences. 81 (2): 152-155.

Nowinszky L. \& Puskás, J. 2012. Light-trap catch of the harmful moths depending on moonlight in North Carolina and Nebraska States of USA. International Scholarly Research Network ISRNZoology, doi. 10.5408/ 2012/238591

Nowinszky L. \& Puskás J. (2013a): The Influence of Moonlight on Forestry Plants Feeding Macrolepidoptera Species, Research Journals of Life Sciences, 13: 1-10.

Nowinszky L. \& Puskás J. (2013b): Light-trap catch of harmful Microlepidoptera species in connection with polarized moonlight and collecting distance Journal of Advanced Laboratory Research in Biology, 4 (4): 108-117.

Nowinszky L. \& Puskás J. (2014): Light-trap catch of Lygus sp. Heteroptera. Miridae in connection with the polarized moonlight, the collecting distance and the staying of the Moon above horizon. Journal of Advanced Laboratory Research in Biology, 5 (4): 102-107.

Nowinszky L. (2003): The Handbook of Light Trapping. SavariaUniversity Press, 276.

Nowinszky L. (2004): Nocturnal illumination and night flying insects. Applied Ecology and Environmental Research. 2 (1): 17-52

Nowinszky L. (2008): Light Trapping and the Moon. Savaria University Press. 170.

Nowinszky L., Barczikay G. \& Puskás J. 2010a. The relationship between lunar phases and the number of pest Microlepidoptera specimens caught by pheromone traps. Asian Journal of Experimental Biological Sciences, 1 (1). 14-: 19.

Nowinszky L., Kiss O., Szentkirályi F., Puskás J., Kádár F. \& Kúti Zs. (2010b): Light trapping efficiency in case of Ecnomus tenellus Rambur Trichoptera. Ecnomidae depending on the moon phases. Advances in Bioreserarch, 12 . 1-5.

Nowinszky L., Hirka A., Csóka Gy., Petrányi G. \& Puskás J. (2012a): The influence of polarized moonlight and collecting distance on the catches of winter moth Operophthera brumata L. Lepidoptera. Geometridae by light-traps. European Journal of Entomology, 109. 29-34.

Nowinszky L., Kiss O., Szentkirályi F., Puskás J. \& Ladányi M. (2012b): Influence of illumination and polarized moonlight on light-trap catch of caddisflies Trichoptera. Research Journal of Biology, 2 (3): 79-90.

Nowinszky L., Puskás, J., Barczikay G. (2015): Pheromone trap catch of harmful Microlepidoptera species in connection with the particulate matter (PM10). e-Acta Naturalia Pannonica, 8: 69-78.

Nowinszky L., Szabó S., Tóth Gy., Ekk I. \& Kiss M. 1979. The effect of the moon phases and of the intensity of polarized moonlight on the light-trap catches. Zeitschtrift für angewandte Entomologie 88: 337-355.

Papanastasiou, D.K., Melas, D. (2004): Analysis and forecast of PM10 concentration in a medium size city. $3^{\text {rd }}$ International Conference on Application of Natural-, Technological- and Economic Sciences. J. Puskás (ed.) Szombathely, pp. 1-8.

Papanastasiou, D.K., Melas, D. (2008): Daily ozone forecasting in an urban area, using meteorological \& pollution data. Fresenius Environmental Bulletin 17(3): 364-370.

Papanastasiou, D.K., Melas, D. (2009): Climatology and impact on air quality of sea breeze in an urban coastal environment. Int. J. Climatol. 29: 305-315.

Papanastasiou, D.K, Melas, D., Bartzanas, T., Kittas, C. (2010): Temperature, comfort and pollution levels during heat waves and the role of sea breeze. International Journal of Biometeorology, 54 (3): 307-317. 
Odor P. \& Iglói L. 1987. An introduction to the sport's biometry in Hungarian (in Hungarian). ÁISH Tudományos Tanácsának Kiadása. Budapest. 267.

Tóth M. 2003. The pheromones and its practical application (in Hungarian). In. Jenser G. ed.. Integrated pest management of pests. Mezőgazda Kiadó, Budapest, 21-50.

Vaskövi B.-né, Udvardy O., Szalkai M., Anda E., Beregszászi T., Nádor G., Varró M. J., Hollósy G.-né, Paller J., B. Brunekreef, R. Beelen, K. Meliefste, G. Hoek, M. Wang, M. Eeftens, K. de Hoogh \& Rudnai P. 2014: Spatial distribution of air pollution in Györ, based on the measurement results of the escape project. (in Hungarian). - Egészségtudomány 58 (1): 8-33.

Zvereva, E., Kozlov, M. ( 2000): Effects of air pollution on natural enemies of the leaf beetle Melasoma lapponica. J. Appl. Ecol. 37: 298-308.

\section{AUTHORS' BIOGRAPHY}

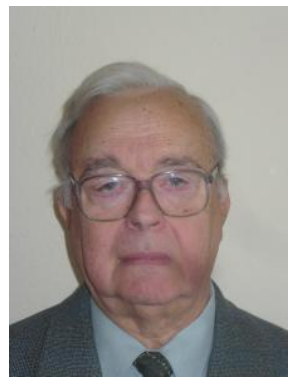

Laszlo Nowinszky made the university studies at the University of Agricultural Sciences, Keszthely (1955-1959). He got a sciences degree (PhD 1991) and habilitation (1998) in the university. He taught at the University of West Hungary, and he retired as a university professor (2006). He made researches in the field of plant protection. He deals with the relationship between the light trapping of insect and biotic and abiotic environmental factors. He wrote three books in Hungarian and five ones in English language. The number of scientific publication is 335 . He has 40 presentations at international conferences. Regularly review scholarly publications request of Hungarian and international learned journals. Member of the editorial boards of scientific journals: Asian Journal of Experimental Biological Sciences, Bulletin of Environment, Pharmacology and Life Sciences, Journal of Advanced Laboratory Research in Biology, Advances in Bioresearch, CTB Science Research Journal of Biological Sciences, Advance Research in Agriculture and Veterinary Science

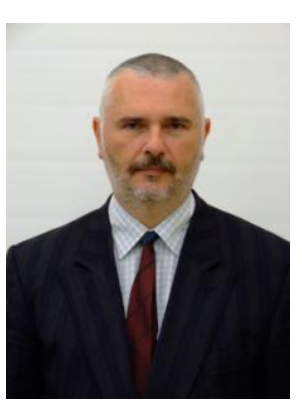

\section{János PUSKÁS}

Occupation or position: Head of Institute, College Professor (Institute of Geography and Environ. Sci.) - University of West Hungary H-9700 Szombathely Károlyi Square 4. Hungary

Guest Professor: St. Steven University PhD School - Biometeorology; University of Debrecen - Biometeorology, Environmental Climatology

Science Degree: 2006 habilitation (University of Debrecen); 1996 PhD (Agricultural University of Pannonia, Keszthely)

Honours: 2013 - Pro Meteorológia Award (Ministry of Rural Development); 2009 - Dénes Berényi Award (Hungarian Meteorological Association); 2009 - Master Teacher Gold Medal (National Students' Scientific Council); 2008 - Pro Geographia Award (Hungarian Geographical Association); 2002 - György Békésy Postdoctoral Fellowship

\section{Gábor BARCZIKAY}

Occupation or position: Plant protection consulting engineer

Name and address of employer: County Borsod-Abaúj-Zemplén Agricultural Office of Plant Protection and Soil Conservation Directorate

Research: pheromone trapping of moth from 1996. 